\title{
AKTIVITAS ANTIBAKTERI EKSTRAK BIJI LABU AIR (Lagenaria siceraria) TERHADAP Staphylococcus epidermidis, Staphylococcus aureus dan Escherichia coli
}

\author{
Silvi Nurafni ${ }^{*}$.,Siti Mariam².,Kasriati ${ }^{3}$ \\ 1. Program Studi Farmasi Sekolah Tinggi Teknologi Industri dan Farmasi Bogor \\ 2. Program Studi FarmasiSekolah Tinggi Teknologi Industri dan Farmasi Bogor \\ 3. Mahasiswa Program Studi S1 Farmasi Sekolah Tinggi Teknologi Industri dan Farmasi Bogor
}

Korespondensi: silvi_nurafni90@yahoo.com

\begin{abstract}
ABSTRAK
Lagenaria siceraria yang dikenal dengan nama biji labu air adalah tanaman yang mengandung senyawa alkaloid, fenol, tanin, flavonoid dan steroid. Senyawa-senyawa diatas berpotensi sebagai antibakteri. Penelitian ini bertujuan untuk mengetahui efektivitas penghambatan pertumbuhan bakteri Staphylococcus epidermidis, Staphylococcus aureus dan Escherichia coli. Berdasarkan hasil penelitian skrining fitokimia dapat diketahui bahwa kandungan biji labu air (Lagenaria siceraria) yaitu alkaloid, tanin, flavonoid, steroid dan fenol. Dari hasil uji efektivitas antibakteri ekstrak biji labu air dengan pelarut etil asetat, heksana dan air mampu menghambat pertumbuhan bakteri Staphylococcus epidermidis, Staphylococcus aureus dan Escherichia coli. Namun aktivitas antibakteri ekstrak biji labu air yang menggunakan pelarut heksana memiliki zona hambat yang lebih besar dibandingkan ekstrak biji labu air yang menggunakan pelarut etil asetat dan air. Perbandingan aktivitas antimikroba pada ketiga pelarut tersebut dengan variasi konsentrasi pelarut menunjukkan perbedaan yang bermakna dalam menghambat pertumbuhan bakteri Staphylococcus epidermidis, Staphylococcus aureus dan Escherichia coli. Hal ini dapat dilihat dari nilai pvalue $<0.05(\mathrm{p}=0,000)$.
\end{abstract}

Kata kunci: Aktivitas Antibakteri, Biji Labu Air, Escherichia coli, Staphylococcus aureus, Staphylococcus epidermidis. 


\begin{abstract}
Lagenaria siceraria, known as water pumpkin seeds containing compounds alkaloids, phenolics, tannins, flavonoids and steroids. The above compounds are potentially as antibacterial. This research aims to know the effectiveness of the inhibition of the growth of the bacteria Staphylococcus epidermidis, Staphylococcus aureus and Escherichia coli. Based on the results of the research it is known that phytochemicals may be screening the content of water pumpkin seeds (Lagenaria siceraria) namely alkaloids, tannins, flavonoids, steroids and phenol. From the results of testing the effectiveness of antibacterial water pumpkin seed extract with ethyl acetate solvent, hexane and water is able to inhibit the growth of Staphylococcus epidermidis, Staphylococcus aureus and Escherichia coli. However the antibacterial activity of extracts of water pumpkin seeds using solvent hexane has a zone larger than drag the extract water pumpkin seeds using the solvent ethyl acetate and water. Comparison of antimicrobial activity of the solvent on the third with variation concentration of solvent shows a meaningful difference in inhibiting the growth of bacteria Staphylococcus epidermidis, Staphylococcus aureus and Escherichia coli. It can be seen from the $\mathrm{p}$-value $<0.05(\mathrm{p}=0.000)$.
\end{abstract}

Keywords: Antibacterial Activity, Water Pumpkin Seeds, Escherichia coli, Staphylococcus aureus, Staphylococcus epidermidis.

\section{PENDAHULUAN}

Bakteri merupakan salah satu jenis mikroorganisme yang banyak dijumpai dalam kehidupan sehari-hari. Dilihat dari sifatnya, bakteri dibagi menjadi dua yakni bakteri yang bersifat menguntungkan dan merugikan. Bakteri yang bersifat merugikan pada umumnya cenderung menjadi salah satu faktor penyebab penyakit.

Salah satu bakteri yang dapat menyebabkan infeksi adalah Staphylococcus epidermidis merupakan bakteri yang bersifat oportunistik (menyerang individu dengan sistem kekebalan tubuh yang lemah) dapat menyebabkan infeksi. Bakteriini merupakan bakteri gram-positif, koloni berwarna putih atau kuning, dan bersifat anaerob fakultatif. Staphylococcus epidermidis dapat menyebabkan infeksi kulit ringan yang disertai dengan pembentukan abses [1]. Sebenarnya Staphylococcus epidermidis adalah flora normal yang terdapat pada manusia. Pada tubuh yang sehat, bakteri ini tidak membahayakan dan tidak menyebabkan penyakit. Bakteri ini hanya berbahaya jika telah menginfeksi, sehingga pertumbuhannya menjadi tidak terkendali.

Bakteri lain yang menyebabkan infeksi adalah Staphylococcus aureus merupakan bakteri gram-positif. Bakteri ini terdapat pada kulit selaput lendir, bisul dan luka. Dapat menyebabkan infeksi luka melalui kemampuannya berkembang biak dan menyebar luas dalam jaringan [2]. Bakteri ini menyebabkan infeksi melalui kontak luka, baik melalui sentuhan tangan yang kotor pada luka atau kontak luka dengan benda lain yang telah terinfeksi Staphylococcus aureus [3].Bakteri lain yang dapat menyebabkan infeksi yaitu Escherichia coli, yaitu bakteri anaerob fakultatif gram-negatif berbentuk batang yang termasuk dalam famili Enterobacteriaceae. Bakteri ini biasa ada pada usus normal, selain berkembang biak dilingkungan sekitar manusia [4].

Pada umumnya infeksi dapat diobati dengan menggunakan antimikroba seperti antiseptik. Antiseptik adalah bahan kimia yang diberikan pada kulit atau jaringan hidup lain untuk menghambat atau membunuh mikroorganisme (baik sementara ataupun menetap) sehingga mengurangi jumlah bakteri [5].

Penggunaan antiseptik yang tidak tepat pada beberapa kasus dapat menyebabkan masalah kekebalan dari antimikrobial dan peningkatan efek samping pemberian antiseptik [6]. Oleh karena itu masyarakat mulai menggunakan obat tradisional untuk mengobati infeksi. Salah satu tanaman yang dapat mengobati infeksi yaitu labu air (Lagenaria siceraria).

Biji labu air (Lagenaria siceraria) mengandung senyawa alkaloid, fenol, tanin, 
flavonoid, dan steroid [7]. Senyawa-senyawa tersebut merupakan senyawa aktif yang dapat berperan dalam proses penyembuhan luka karena dapat menghambat pertumbuhan bakteri pada jaringan hidup [8].

Berdasarkan penjelasan di atas ekstrak biji labu air (Lagenaria siceraria) mempunyai aktivitas antibakteri, namunperlu dilakukan penelitian apakah senyawa antibakteri yang terdapat pada biji labu air merupakan senyawa polar atau non-polar. Biji labu air (Lagenaria siceraria) akan diekstraksi menggunakan tiga pelarut yaitu etil asetat, heksana dan air yang kemudian akan dilakukan uji aktivitas antibakterinya terhadap bakteriStaphylococcus epidermidis, Staphylococcus aureus dan Escherichia coli.

\section{METODE PENELITIAN}

Bahan: Bahan yang digunakan dalam penelitian ini adalah biji labu air (Lagenaria siceraria), etil asetat, akuades, heksana, alkohol, media NA (Nutrient Agar) 1,5\%, media NB (Nutrient Bort) $1,5 \%, \quad \mathrm{NaCl}$, Kloramfenikol $1 \%$, bakteri Staphylococcus aureus, bakteri Staphylococcus epidermidis, bakteri Escherichia coli

Alat: Alat yang digunakan dalam penelitian ini adalah botol coklat, aluminium foil, batang pengaduk, kertas saring, tabung reaksi, labu ukur, timbangan analitik, oven, erlenmeyer, pipet tetes, sarung tangan, masker, evaporator, blender, ayakan mesh 60, cawan petri, beaker glass, kertas coklat, kaki tiga, spirtus, kawat ose, autoklaf

\section{Metode Preparasi Sampel}

Siapkan buah labu air lalu dibelah dan diambil biji labu air. Disortasi basah pada biji labu air dengan cara memisahkan kotorankotoran atau bahan-bahan asing lainnya dari bahan simplisia. Biji labu air dicuci hingga bersih. Simplisia dikeringkan menggunakan oven pada suhu $70^{\circ} \mathrm{C}$ selama $1 \times 24$ jam. Disortasi kering dengan tujuan untuk memisahkan bahan asing seperti bagian-bagian tanaman yang tidak diinginkan dan pengotoran-pengotoran lainnya yang masih ada dan tertinggal pada simplisia kering. Simplisia dihaluskan menggunakan blender. Diayak mengunakan mesh no 40. Simplisia kering ditimbang menggunakan timbangan analitik.

\section{Penentuan Kadar Air}

Siapkan cawan penguap dipanaskan dan ditara sampai bobot tetap. Ambil simplisia kering biji labu air sebanyak $2 \mathrm{~g}$, dimasukkan ke dalam cawan penguap yang sudah ditara. Masukkan ke dalam oven berulang kali pada suhu $105^{\circ} \mathrm{C}$ selama 30 menit dan ditimbang sampai konstan (bobot tetap). Sebelum dimasukkan oven dan setelah pemanasan dimasukkan dalam deksikator hingga suhu kamar. Kemudian didinginkan dan ditimbang kembali. Rumus perhitungan kadar air, sebagai berikut:

$$
\text { Kadar air }(\%)=\frac{a-b}{a} \times 100 \%
$$

$\mathrm{a}=$ bobot sampel sebelum pemanasan $(\mathrm{g})$

$\mathrm{b}=$ bobot sampel setelah pemanasan $(\mathrm{g})$

\section{Pembuatan Ekstrak Etil Asetat Biji Labu Air}

Langkah-langkah pembuatan ekstrak etil asetat biji labu air, simplisia biji labu air sebanyak $100 \mathrm{~g}$ dimasukkan ke dalam botol coklat. Ditambahkan pelarut etil asetat sebanyak $400 \mathrm{ml}$. Botol coklat ditutup rapat dan dilapisi dengan alumunium foil. Rendaman simplisia disimpan selama $1 \times 24$ jam sambil diaduk setiap hari selama 3 hari. Saring hasil rendaman untuk memisahkan residu dengan filtrat.

\section{Pembuatan Ekstrak Heksana Biji Labu Air}

Ampas dari etil asetat biji labu air dimasukkan ke dalam botol coklat.Tambahkan pelarut heksana sebanyak $400 \mathrm{ml}$.Botol coklat ditutup rapat dan dilapisi dengan aluminium foil.Rendaman simplisia disimpan selama $1 \times 24$ jam sambil diaduk setiap hari selama 3 hari. Saring hasil rendaman untuk memisahkan residu dengan filtrat.

\section{Pembuatan Ekstrak Air Biji Labu Air}

Ampas dari heksana dari biji labu air dimasukkan ke dalam botol coklat. Tambahkan air sebanyak $400 \mathrm{ml}$. Botol coklat ditutup rapat dan dilapisi dengan aluminium foil. Rendaman simplisia disimpan selama $1 \times 24$ jam sambil diaduk setiap hari selama 3 hari. Saring hasil 
rendaman untuk memisahkan residu dengan filtrat.

Ekstrak kental yang diperoleh kemudian dihitung $\%$ rendemennya dengan rumus:

$$
\text { Rendemen }=\frac{\text { bobotekstrakkental }}{\text { bobotserbuk }} \times 100 \%
$$

\section{Uji Fitokimia[9]}

a. Uji Alkaloid

Sebanyak $5 \mathrm{ml}$ sampel dilarutkan dengan beberapa tetes asam sulfat $2 \mathrm{~N}$ lalu diuji dengan pereaksi alkaloid yaitu Pereaksi Mayer, Pereaksi Wagner dan Pereaksi Dragendorff. Hasil uji positif adanya senyawa flavonoid ditandai dengan terbentuknya endapan berturut-turut putih Pereaksi Mayer, endapan kuning kecoklatan Pereaksi Wagner dan endapan merah jingga Pereaksi Dragendorff.

b. Uji Flavonoid

Sebanyak $5 \mathrm{ml}$ sampel ditambahkan $0,5 \mathrm{mg}$ serbuk $\mathrm{Mg}, 1 \mathrm{ml} \mathrm{HCl}$ pekat dan $1 \mathrm{~mL}$ amil alkohol. Campuran dikocok kuat, munculnya warna merah dan kuning positif menunjukkan adanya flavonoid.

c. Uji Fenol

Ekstrak ditambahkan dengan $1 \mathrm{ml}$ larutan $\mathrm{Fe}(\mathrm{III})$ klorida $10 \%$. Jika terbentuk warna biru tua, biru kehitaman atau hitam kehijauan menunjukkan adanya senyawa polifenol dan tanin (Robinson, 1995; Jones dan Kinghorn, 2006).

d. Uji Tanin

Sebanyak $5 \mathrm{ml}$ sampel ditambahkan air hingga warnanya memudar. Kemudian diambil $2 \mathrm{ml}$ dan ditetesi $1-2$ tetes pereaksi $\mathrm{FeCl}_{3}$. Hasil uji positif ditandai dengan munculnya warna hijau, biru atau kehitaman.

\section{e. Uji Steroid}

Sebanyak $5 \mathrm{ml}$ larutan sampel ditambahkan $2 \mathrm{ml}$ kloroform dalam tabung reaksi yang kering, lalu ditambahkan 10 tetes asetat anhidrat dan 3 tetes asam sulfat pekat. Reaksi positif ditunjukkan dengan terbentuknya larutan berwarna merah untuk pertama kali lalu berubah menjadi warna biru atau hijau untuk steroid serta merah atau ungu untuk triterpenoid.

\section{Uji aktivitas ekstrak labu biji air terhadap bakteri Staphylococcus epidermidis, Staphylococccus aureus dan Escherichia coli}

a. Penyiapan Media NA (Nutrient Agar) dan sterilisasi alat

Alat dicuci dengan menggunakan sabun kemudian dikeringkan. Media NA (Nutrient Agar) sebanyak 1,5\% dimasukkan ke dalam erlenmeyer kemudian ditambahkan akuades masak hingga mendidih sambil diaduk dengan batang pengaduk. Setelah media NA larut selanjutnya dibiarkan sampai hangat. Alat yang akan disterilisasi dibungkus dengan kertas coklat, sedangkan media yang akan disterilkan ditutup menggunakan kapas kemudian ditutup menggunakan alumunium foil. Masukkan alat dan bahan yang akan disterilkan ke dalam autoklaf pada suhu $121^{\circ} \mathrm{C}$, selama \pm 3 jam sampai jarum menunjukkan pada garis berwarna hijau dan di diamkan selama 15 menit.

b. Penyiapan Media dan inokulasi bakteri Tuang media NA (Nutrient Agar) yang sudah disterilisasi ke dalam tabung reaksi (lakukan secara aseptis), tunggu hingga mengeras dalam keadaan miring. Ambil isolat bakteri dari biakan miring, kemudian diinokulasikan pada media NA (Nutrient Agar). Diinkubasi pada suhu $37^{\circ} \mathrm{C}$ selama $24-36$ jam.

c. Peremajaan bakteri pada media NB (Nutrient borth)

Timbang NB sebanyak 1,5 g larutkan dalam $100 \mathrm{ml}$ akuades selanjutnya disteril menggunakan autoklaf, setelah steril ambil biakan bakteri Staphylococcus epidermidis dengan cara aseptis digores secukupnya menggunakan jarum ose masukkan kedalam media cair NBselanjutnya tunggu 1x24 jam. Pertumbuhan bakteri ditunjukkan dengan terbentuknya media yang keruh. Perlakuan sama pada bakteri Staphylococcus aureus dan Escherichia coli.

d. Pengujian antibakteri ekstrak biji labu air Siapkan media NA (Nutrient Agar) steril dan ekstrak biji labu air dengan dosis 600 $\mathrm{mg}, 500 \mathrm{mg}, 400 \mathrm{mg}, 300 \mathrm{mg}$. Media NA cair dimasukkan dalam cawan petri pada suhu $\pm 45^{\circ} \mathrm{C}$, kemudian ke dua cawan petri diputar membentuk angka 8 untuk dihomogenkan. Ambil media NB yang berisi bakteri Staphylococcus epidermidis 
masukkan pada cawan petri (diulangi 1 kali untuk kontrol positif). Ekstrak biji labu air dimasukkan pada sedian media NA yang sudah padat menggunakan metode kertas cakram. Diinkubasi selama 18-24 jam pada suhu $37^{\circ} \mathrm{C}$. Diamati, diukur dan dibandingkan zona bening yang terbentuk disekitar sumuran menggunakan jangka sorong. Lakukan perlakuan sama dengan bakteri Staphylococcus aureus dan Escherichia coli.

e. Pengujian kloramfenikol sebagai kontrol positif

Siapkan media NA (Nutrient Agar) steril dan kloramfenikol 1\%. Selajutnya media NA cair dimasukkan dalam cawan petri pada suhu $\pm 45^{\circ} \mathrm{C}$, kemudian ke dua cawan petri diputar membentuk angka 8 untuk dihomogenkan biarkan mengeras. Ambil media NB yang berisi bakteri Staphylococcus epidermidis masukkan pada cawan petri yang sudah terlebih dahulu dimasukkan media padat NA. Selanjutnya masukkan kloramfenikol 1\% media NA yang sudah padat menggunakan metode kertas cakram. Diinkubasi selama 18-24 jam pada suhu $37^{\circ} \mathrm{C}$. Diamati, diukur dan dibandingkan zona bening yang terbentuk disekitar sumuran menggunakan jangka sorong. Lakukan perlakuan sama dengan bakteri Staphylococcus aureus dan Escherichia coli.

\section{ANALISA DATA}

Data yang dikumpulkan adalah data primer yang didapatkan dari pengukuran diameter zona hambat dari masing-masing bakteri pada tiap - tiap perlakuan ekstrak daun sirsak. Data hasil penelitian diolah dan disajikan dalam bentuk tabel dan grafik. Selanjutnya untuk menganalisis ada tidaknya perbedaan aktivitas antibakteri pada tiap-tiap perlakuan (variasi pelarut dan variasi konsentrasi pelarut) digunakan uji Multivariate Analysis of Variance (MANOVA).

\section{HASIL DAN PEMBAHASAN Simplisia}

Sampel yang digunakan pada penelitian ini adalah biji labu air (Lagenaria sieraria). Simplisia labu biji air dibuat serbuk dan diayak dengan pengayak 40 mesh.Setelah pengayakan, serbuk biji labu air diukur kadar airnya. Penentuan kadar air berguna untuk mengetahui batasan maksimal atau kisaran kandungan air dalam bahan. Hal ini berhubungan dengan daya simpan simplisia, sehingga jika melebihi batas yang ditentukan sangat mempengaruhi waktu kadaluarsa dari simplisia tersebut. Semakin tinggi kadar air, maka semakin mudah ditumbuhi jamur dan kapang sehingga dapat menurunkan aktivitas biologi senyawa aktif selama penyimpanan. Persyaratan kadar air yang berupa ptongan simplisia atau campuran simplisia kadara air tidak boleh lebih dari 10\%.[9]

Hasil penetapan kadar air yang diperoleh pada penelitian ini adalah $8,9 \%$ yang artinya kadar air ekstrak biji labu air telah memenuhi persyaratan sehingga tidak mudah ditumbuhi jamur dan kapang, serta dapat disimpan dalam waktu yang cukup lama.

\section{Hasil Ekstraksi Biji Labu Air}

Sampel biji labu air diekstraksi dengan tujuan untuk memisahkan komponen kimia yang terdapat pada biji labu air. Metode ekstraksi yang digunakan pada penelitian ini, yaitu maserasi dengan 3 pelarut yaitu etil asetat, heksana dan air. Ketiga pelarut ini mempunyai kepolaran yang berbeda dimana etil asetat adalah pelarut semi polar, heksana adalah pelarut non polar, dan air adalah pelarut polar. Pemilihan metode maserasi dikarenakan maserasi merupakan metode yang paling mudah dan sederhana, tidak memerlukan peralatan yang khusus serta suhu yang yang digunakan rendah sehingga dapat mencegah penguraian senyawa yang tidak tahan panas. Ekstrak yang diperoleh dari hasil ekstraksi ini dipekatkan dan dihasilkan ekstrak kental. Persen rendemennya adalah 10,06\% (ekstrak etil asetat), 9,34\% (ekstrak heksana) dan $12,09 \%$ (ekstrak air).

\section{Hasil Fitokimia Ekstrak Etil Asetat, Ekstrak Heksana dan Ekstrak Air Biji Labu Air}

Uji fitokimia dalam penelitian ini dilakukan bertujuan menganalisis keberadaan senyawa yang diduga memiliki aktivitas antibakteri dalam ketiga ekstrak biji labu air. Penapisan dilakukan terhadap golongan senyawa alkaloid, flavonoid, steroid, fenol dan tanin.Hasil uji fitokimia terhadap ekstrak etil asetat biji labu air menunjukkan hasil positif 
pada uji flavonoid, tanin, steroid dan alkaloid sedangkan pada uji fenol menunjukkan hasil negatif yang ditandai dengan tidak adanya perubahan warna.

Pada ekstrak heksana biji labu air menunjukkan hasil positif adalah uji alkaloid dan steroid dan hasil negatif diperoleh pada uji flavonoid, fenol dan tanin. Sedangkan uji fitokimia terhadap ekstrak air biji labu air menunjukkan hasil positif pada uji alkaloid pereaksi Mayer, tanin, flavonoid dan fenol sebaliknya hasil negatif didapat pada uji alkaloid pereaksi Wagner dan Dragendrof dan uji steroid. Uji fitokimia memberikan tanda hasil yang spesifik untuk setiap ujinya.

Tabel 1. Hasil Uji Fitokimia dari Ekstrak Biji Labu Air

\begin{tabular}{|c|c|c|c|c|c|}
\hline \multirow[b]{2}{*}{ No } & \multirow[b]{2}{*}{ Senyawa } & \multicolumn{3}{|c|}{ Sampel } & \multirow[b]{2}{*}{ Keterangan } \\
\hline & & $\begin{array}{l}\text { Ekstrak Etil } \\
\text { Asetat }\end{array}$ & $\begin{array}{l}\text { Ekstrak } \\
\text { Heksana }\end{array}$ & $\begin{array}{l}\text { Ekstrak } \\
\text { Air }\end{array}$ & \\
\hline \multirow{4}{*}{1} & Alkaloid & + & & & \\
\hline & Meyer & + & + & + & Endapan putih \\
\hline & Dragendrof & + & + & - & Endapan jingga \\
\hline & Wagner & & + & - & Endapan coklat \\
\hline 2 & Flavonoid & + & - & + & Jingga \\
\hline 3 & Steroid & + & + & - & $\begin{array}{c}\text { Larutan } \\
\text { Hijau/Biru }\end{array}$ \\
\hline 4 & Tanin & + & - & + & $\begin{array}{l}\text { Larutan Hitam } \\
\text { Kehijauan }\end{array}$ \\
\hline 5 & Fenol & - & - & + & $\begin{array}{l}\text { Larutan Biru } \\
\text { Kehitaman }\end{array}$ \\
\hline
\end{tabular}

Keterangan :(+) : Positif, mengandung zat aktif

$(-)$ : Negatif, tidak mengandung zat aktif 


\section{Hasil Uji Aktivitas Antibakteri Pada Biji}

\section{Labu Air}

Aktivitas antibakteri dari ekstrak etil asetat, heksana dan air biji labu air terhadap bakteri Staphylococcus aureus, Staphylococcus epidermidis dan E.coli ditunjukkan dengan timbulnya zona hambat pertumbuhan pada bakteri.

Tabel 2. Kategori Diameter Zona Hambat [10]

\begin{tabular}{|l|l|}
\hline Diameter $(\mathrm{mm})$ & $\begin{array}{l}\text { Kategori } \\
\text { Antimikroba }\end{array}$ \\
\hline$<5$ & Lemah \\
\hline $6-10$ & Sedang \\
\hline $11-20$ & Kuat \\
\hline$>21$ & Sangat kuat \\
\hline
\end{tabular}

Dari tabel 2 diatas dapat dilihat bahwa diameter zona hambat sebanding dengan aktivitasnya, dimana semakin besar diameter zona hambat menunjukkan aktivitas antibakteri yang semakin kuat.

Tabel 3. Zona Hambat pada Bakteri Staphylococcus aureus

\begin{tabular}{|c|c|c|c|c|c|}
\hline \multirow{2}{*}{$\begin{array}{c}\text { Konsentrasi } \\
\text { Ekstrak }\end{array}$} & \multicolumn{3}{|c|}{ Pelarut } & Kloramfenikol & \multirow{2}{*}{ P-value } \\
\cline { 2 - 5 } (Kontrol +) & Etil Asetat & Heksana & Air & \\
\hline $300 \mathrm{mg}$ & $0.26 \mathrm{~mm}$ & $1.52 \mathrm{~mm}$ & $0.19 \mathrm{~mm}$ & $5.07 \mathrm{~mm}$ & \\
\hline $400 \mathrm{mg}$ & $0.37 \mathrm{~mm}$ & $1.60 \mathrm{~mm}$ & $0.29 \mathrm{~mm}$ & $5.09 \mathrm{~mm}$ & \multirow{2}{*}{0.000} \\
\hline $500 \mathrm{mg}$ & $0.46 \mathrm{~mm}$ & $1.71 \mathrm{~mm}$ & $0.40 \mathrm{~mm}$ & $5.10 \mathrm{~mm}$ & \\
\hline $600 \mathrm{mg}$ & $0.64 \mathrm{~mm}$ & $1.81 \mathrm{~mm}$ & $0.52 \mathrm{~mm}$ & $5.13 \mathrm{~mm}$ & \\
\hline
\end{tabular}

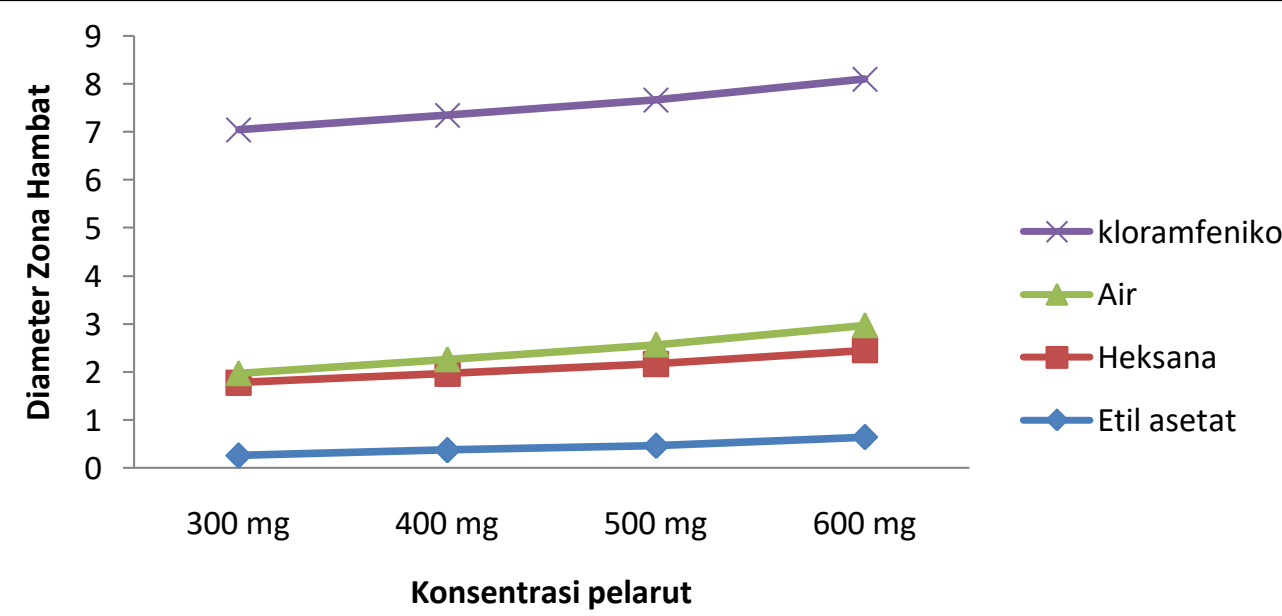

Gambar 1. Grafik Zona Hambat Ekstrak terhadap Staphylococcus aureus 
Pada tabel dan grafik diatas dapat dilihat hasil uji daya hambat terhadap Staphylococcus aureus menunjukkan zona hambat ekstrak heksana lebih tinggi dibanding ekstrak etil asetat dan air. Perbedaan zona hambat terhadap Staphylococcus aureus dari ketiga ekstrak tersebut bermakna dapat dilihat dari nilai $p$-value $\quad 0,005 \quad(\mathrm{p}=0,000) . \quad \mathrm{Hal}$ ini menunjukkan bahan senyawa aktif antimikroba pada biji labu air merupakan senyawa non polar. Berdasarkan hasil uji fitokimia ekstrak heksana mengandung alkaloid dan steroid, sedangkan pada ekstrak air tidak mengandung alkaloid. Alkaloid pada tanaman terdapat dalam dua bentuk yaitu alkaloid bebas yang larut pada senyawa non polar dan alkaloid bentuk garam yang larut pada pelarut polar. Etil asetat merupakan senyawa semi polar sehingga alkaloid dan steroid ikut tertarik tetapi kandungannya lebih rendah daripada steroid dan alkaloid yang tertarik pada heksana, senyawa yang terkandung pada ekstrak heksana biji labu air mempunyai aktivitas antimikroba lemah karena kurang dari $<5 \mathrm{~mm}$ terhadap bakteri gram positif yaitu Staphylococcus aureus. Peningkatan dosis ekstrak yang diberikan menunjukkan peningkatan aktivitas antimikroba terhadap Staphylococcus aureus.

b. Zona Hambat Staphylococcus epidermidis Rata-rata zona hambat ekstrak biji labu air terhadap bakteri Staphylococcus epidermidis dapat dilihat pada tabel 4 dan gambar 2 di bawah ini.

Tabel 4. Zona Hambat pada Bakteri Staphylococcus epidermidis

\begin{tabular}{|c|c|c|c|c|c|}
\hline \multirow{2}{*}{$\begin{array}{c}\text { Konsentrasi } \\
\text { Ekstrak }\end{array}$} & \multicolumn{3}{|c|}{ Pelarut } & Kloramfeniko & \multirow{2}{*}{ Pvalue } \\
\cline { 2 - 5 } & Etil Asetat & Heksana & Air & Kontrol +) & \\
\hline $300 \mathrm{mg}$ & $0.15 \mathrm{~mm}$ & $0.53 \mathrm{~mm}$ & $0.02 \mathrm{~mm}$ & $5.09 \mathrm{~mm}$ & \\
\cline { 1 - 5 } $400 \mathrm{mg}$ & $0.27 \mathrm{~mm}$ & $1.28 \mathrm{~mm}$ & $0.13 \mathrm{~mm}$ & $5.10 \mathrm{~mm}$ & \multirow{2}{*}{0.000} \\
\cline { 1 - 5 } $500 \mathrm{mg}$ & $0.35 \mathrm{~mm}$ & $1.34 \mathrm{~mm}$ & $0.21 \mathrm{~mm}$ & $5.12 \mathrm{~mm}$ & \\
\cline { 1 - 5 } $600 \mathrm{mg}$ & $0.46 \mathrm{~mm}$ & $1.49 \mathrm{~mm}$ & $0.38 \mathrm{~mm}$ & $5.15 \mathrm{~mm}$ & \\
\hline
\end{tabular}

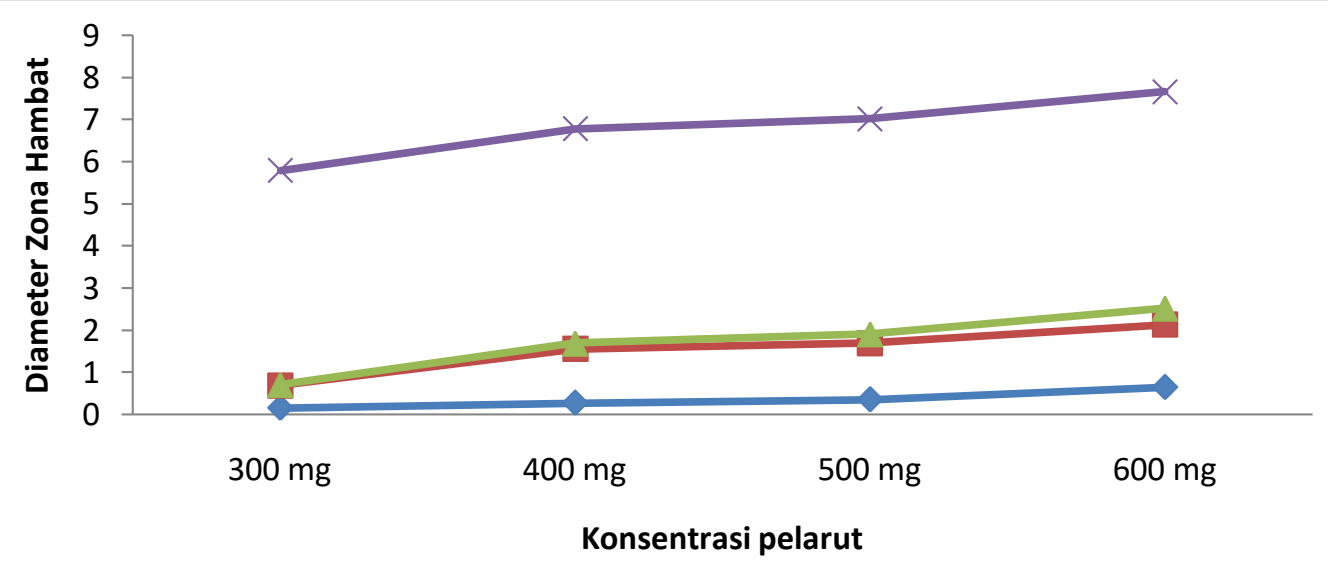

Gambar 2. Grafik zona hambat ekstrak terhadap Staphylococcus epidermidis

Pada tabel dan grafik diatas dapat dilihat hasil uji aktivitas antimikroba ekstrak biji labu air pada Staphylococcus epidermidis menunjukkan zona hambat yang tinggi pada ekstrak heksana dibanding ekstrak air dan etil asetat. Perbedaan zona hambat terhadap
Staphylococcus epidermidis dari ketiga ekstrak tersebut bermakna dapat dilihat dari nilai $p$-value $<0,005(\mathrm{p}=0,000)$. Hal ini menunjukkan bahwa senyawa yang terdapat pada ekstrak heksana biji labu air efektif menghambat pertumbuhan bakteri gram positif yaitu Stahylococcus 
epidermidis dan Staphylococcus aureus. Penghambatan pada Staphylococcus aureus lebih besar dibanding pada Staphylococcus epidermidis. Peningkatan dosis ekstrak yang diberikan menunjukkan peningkatan aktivitas antimikroba terhadap Staphylococcus epidermidis. Pada semua pelarut dengan dosis $300 \mathrm{mg}, 400 \mathrm{mg}, 500$ $\mathrm{mg}$ dan $600 \mathrm{mg}$ dikatakan zona beningnya lemah karena $<5 \mathrm{~mm}$.

c. Zona Hambat Escherichia coli

Rata-rata zona hambat ekstrak biji labu air terhadap bakteri Escherichia coli dapat dilihat pada tabel 5 dan gambar 3 di bawah ini.

Tabel 5. Zona Hambat pada Bakteri Escherichia coli

\begin{tabular}{|c|c|c|c|c|c|}
\hline \multirow{2}{*}{$\begin{array}{c}\text { Konsentrasi } \\
\text { Ekstrak }\end{array}$} & \multicolumn{3}{|c|}{ Pelarut } & \multirow{2}{*}{$\begin{array}{c}\text { Kloramfenikol } \\
\text { (Kontrol +) }\end{array}$} & \multirow{2}{*}{ Pvalue } \\
\cline { 2 - 5 } & Etil Asetat & Heksana & air & \multirow{2}{*}{0.000} \\
\cline { 1 - 4 } $300 \mathrm{mg}$ & $0.36 \mathrm{~mm}$ & $0.52 \mathrm{~mm}$ & $0.23 \mathrm{~mm}$ & $5.09 \mathrm{~mm}$ & \\
\cline { 1 - 4 } $400 \mathrm{mg}$ & $0.43 \mathrm{~mm}$ & $0.68 \mathrm{~mm}$ & $0.34 \mathrm{~mm}$ & $5.1 \mathrm{~mm}$ & \\
\cline { 1 - 4 } $500 \mathrm{mg}$ & $0.55 \mathrm{~mm}$ & $0.47 \mathrm{~mm}$ & $0.36 \mathrm{~mm}$ & $5.12 \mathrm{~mm}$ & \\
\cline { 1 - 4 } $600 \mathrm{mg}$ & $0.65 \mathrm{~mm}$ & $0.48 \mathrm{~mm}$ & $0.52 \mathrm{~mm}$ & $5.15 \mathrm{~mm}$ & \\
\hline
\end{tabular}

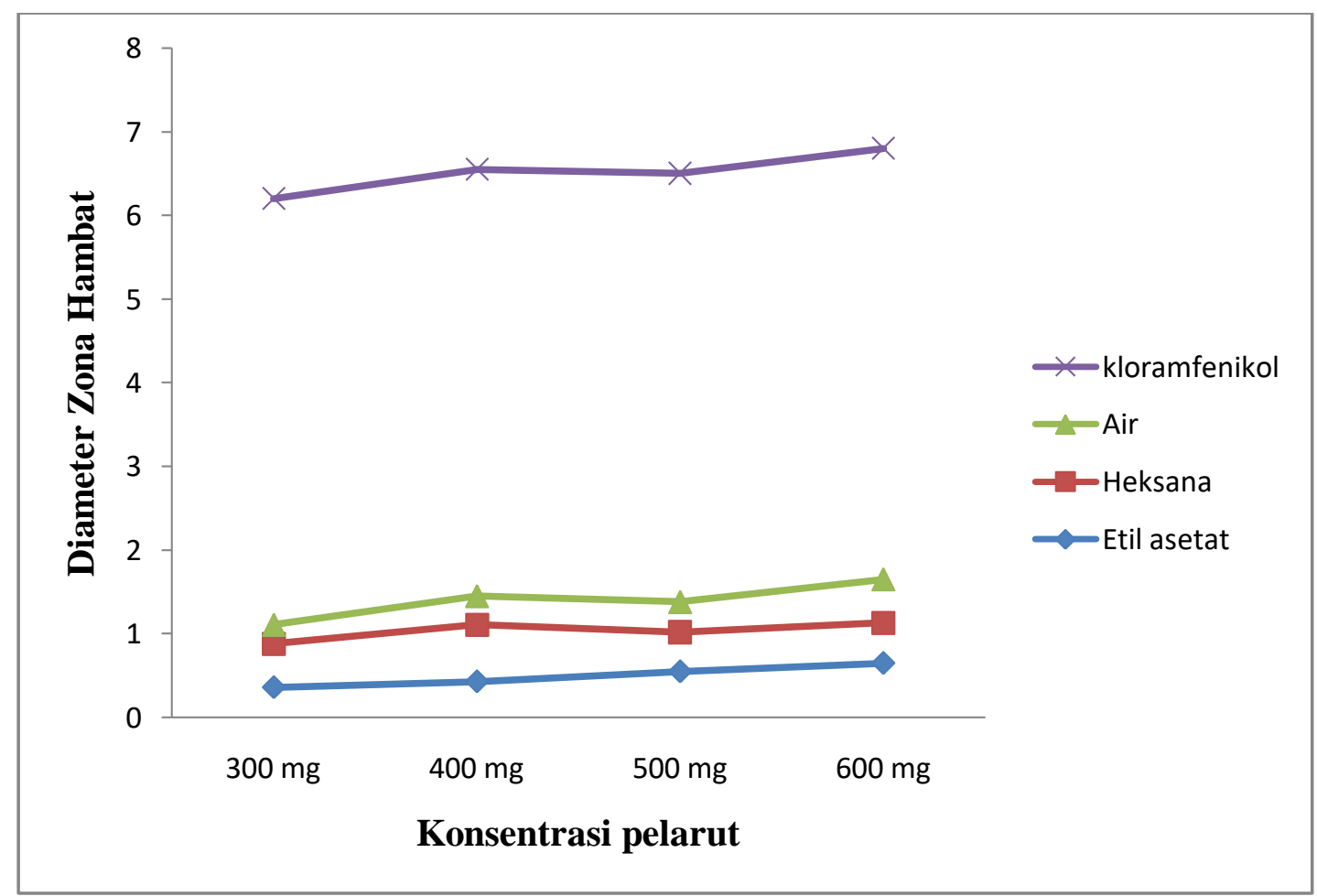

Gambar 3. Grafik zona hambat terhadap Escherichia coli 
Pada tabel dan grafik diatas dapat dilihat hasil uji ekstrak biji labu air pada bakteri Escherichia coli menunjukkan zona hambat yang paling besar pada pelarut heksana yang merupakan senyawa non polar, dibandingkan dengan pelarut air dan etil asetat. . Perbedaan zona hambat terhadap Escherichia coli dari ketiga ekstrak tersebut bermakna dapat dilihat dari nilai $p$-value $<0,005$ $(\mathrm{p}=0,000)$. Pada uji fitokimia heksana dapat menarik senyawa-senyawa non polar seperti alkaloid dan steroid, sedangkan pada etil asetat yang bersifat semi polar dapat menarik sedikit senyawa polar dan non polar. Ekstrak air dapat menarik senyawa tanin, flavonoid dan fenol. Falvonoid bekerja dengan cara merusak membrane sitoplasma sehingga bakteri akan rusak dan mati mekanisme ini dapt terjadi akibat reaksi antara senyawa lipid dan asam amino dengan gugus alkaloid pada flavonoid, sehingga dinding sel mengalami kerusakan dan mengakibatkan senyawa tersebut dapat masuk kedalam inti sel bakteri. Senyawa ini kemudian akan bereaksi dengan DNA pada inti sel bakteri. Akibat perbedaan kepolaran antara lipid dan penyusun DNA dengan gugus alkohol pada senyawa flavonoid akan terjadi reaksi sehingga struktur lipid dari DNA bakteri sebagai inti sel bakteri akan mengalamai kerusakan dan lisis. Tiga mekanisme yang dimiliki flavonoid dalam memberikan efek antibakteri, antara lain: menghambat sintesis asam nukleat, menghambat fungsi membrane sitoplasma dan menghambat metabolisme energi [11].

Tanin juga memiliki kemampuan menghambat pertumbuhan bakteri dengan cara menginaktivasi enzim kelangsungan aktivitas bakteri tergantung pada kerja enzim. Apabila kerja enzim terganggu, otomatis enzim akan membutuhkan energi dalam jumlah yang relatif besar untuk aktivitasnya, sehingga memungkinkan energi untuk pertumbuhan bakteri menjadi berkurang. Apabila hal tersebut berlangsung lama maka aktivitas bakteri akan terhambat dan lisis bahkan inaktif [12].Sehingga hal ini menunjukkan bahwa senyawa heksana yang terdapat pada labu air paling efektif untuk menghambat pertumbuhan bakteri gram negatif. Peningkatan dosis ekstrak yang diberikan menunjukkan peningkatan aktifitas antimikroba terhadap Escherichia coli. Pada semua pelarut dengan dosis $300 \mathrm{mg}, 400 \mathrm{mg}$, $500 \mathrm{mg}$ dan $600 \mathrm{mg}$ dikatakan zona beningnya lemah karena $<5 \mathrm{~mm}$.

\section{SIMPULAN}

Hasil penelitian menunjukkan ekstrak etil asetat, heksana dan air dengan variasi konsentrasi pelarut dari biji labu air mampu menghambat pertumbuhan bakteri Staphylococcus epidermidis, Staphylococcus aureus dan Escherichia coli. Perbandingan aktivitas antimikroba padaekstrak etil asetat, heksana dan air dengan variasi konsentrasi pelarut menunjukkan perbedaan yang bermakna dalam menghambat pertumbuhan bakteri Staphylococcus epidermidis, Staphylococcus aureus dan Escherichia coli. Hal ini dapat dilihat dari nilai pvalue $<0.05$ $(\mathrm{p}=0,000)$.

\section{SARAN}

Perlu dilakukan penelitian lebih lanjut untuk menguji aktivitas terhadap mikroorganisme lain.

\section{DAFTAR PUSTAKA}

[1] Radji, Maksum, 2011. Buku Ajar, MIKROBIOLOGI (Panduan Mahasiswa Farmasi dan Kedokteran. Jakarta: Penerbit Buku kedokteran EGC,pp. 180181.

[2\}Kusuma, Sri Agung Fitri,M.Si., Apt, 2009. Staphylococcus aureus [makalah]. Jatinangor: Universitas Padjadjaran Fakultas Farmasi.

[3] Baroroh, Dewi B, 2011. Konsep luka, basic nursing department, PSIK FIKES UMM.

[4]Arisman, 2009. Buku Ajar Ilmu Gizi Keracunan Makanan. Jakarta: EGC. Hal. 93.

[5]Irwan et al, 2012.ChlorhexidineAlcohol versus Povidone Iodine for Surgical-Site Antisepsis. Purwokerto: Fakultas kedokteran dan ilmu-ilmu kesehatanuniversitas jenderal soedirman

[6] Yasin et al, 2009. Bacteriological status of drinking water in the periurban areas of Rawalpindi and IslamabadPakistan.African Journal of Microbiology Research Vol. 6(1), pp. 169-175, 9 
[7] The Wealth of India, 2004. A Dictionary of Indian raw materials \& industrial products. CSIR, New Delhi III, 16-19.

[8]Harris. 2011. "Pengaruh Substitusi Ubi Jalar (Ipomea batatas) dengan Susu Skim terhadap Pembuatan Es Krim" (Skripsi S-1 Program Studi Teknologi Pangan). Makassar : Universitas Hasanuddin.

[9] Harborne, 1996. Metode Fitokimia Penuntun Cara Modern Menganalisis Tumbuhan. Terbitan kedua. Terjemahan K. Padmawinata dan 1. Soediro. Bandung: ITB.

[10]Absor ulil, 2006. Aktivitas Antibakteri Ranting Patah Tulang (Euphorbia tirucalli. Linn). Bogor: IPB.

[11]Cushnie TPT, Lamb AJ. Antimicrobial activity of flavonoids. Int $\mathbf{J}$ Antimicrob Agents. 2005;26:343-356. [PubMed]

[12]Santoso et al, 2013. Metode Baru Sintesis 3,4-metilenadioksibenzil Butil Eter. Surabaya:ITS 